\title{
Character and Student Ability of Covid-19 Understanding in Digital Era In 2020
}

\author{
Allif Syahputra Bania ${ }^{1}$, Nuraini' ${ }^{2}$, Maria Ulfa ${ }^{3}$ \\ ${ }^{1,2,3}$ Faculty of Teacher Training and Education, Universitas Samudra, Indonesia \\ allifbania@unsam.ac.id
}

\section{Abstract}

The purpose of this research is to describe the character of students towards the understanding of Covid-19 in the digital age, to describe the ability of students to translate understanding of terminology relating to Covid-19 in the digital age, and to describe the effectiveness of digital campus on understanding covid-19 by students in the digital age. The data analysis technique in this research is quantitative descriptive. The result shows that The ability of students to translate intralingually new words that were present during the Covid-19 period is very good and dominant in number. The dominant character of students in putting an interest in the knowledge, learning and translation of new words during the Covid-19 pandemic to deal with the spread of Covid-19 was very good, interested, uplifting and enthusiastic. The level of effectiveness of digital campuss by students when the corona pandemic is very high and dominant. Thank you to the LPPM \& PM Universitas Samudra from the DIPA 2020 funds and all those who assisted our research activities so that we can complete the flagship basic research.
Keywords

character, translate; covid-19; digital

era

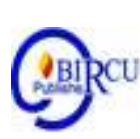

\section{Introduction}

The world of academics has arrived at the gate of the digital age. Information is spread globally and quickly without a limited space and time. Access to learning is easy to obtain, store and process by teachers and students. The advancements in digital technology open the world network of academics to be able to take advantage of online teaching and learning activities or can be called online lectures. Online lecture media are communicated via a variety of applications that are easy to install on gadgets both in the form of unlimited text and data transfers without face to face such as email or who can face to face in real time utilizing Skype, zoom and even What Sapp video calls.

With the development of digital technology and information, learning is commonly known today with the concept of a virtual university or cyber university where the campus must be able to improve itself and contribute significantly to keep abreast of current developments that are increasingly dynamic and up to date. Cyber University is linked to learning mechanisms that use computer and internet assistance as the main base of successful implementation so as to bring up new terminology such as distance learning, e-education and e-classes. In 2020, the general public as well as global academics enter into a phase of dependence on mobile use, gadgets or smartphones where conciseness and convenience are felt to be very useful in the digital era so that cyber universities experience a branch marking process on the role of traditional universities. The interrelated process between cyber and traditional universities regarding the rise in mobile usage has led to the study of distance 
learning that does not depend on the place or the real world differences in the virtual world, namely notebook-university (tablet PC-university) which is more focused on digital campus than just virtual / cyber university.

Digital era facilitate humans in accessing various information where the information can be in the form of good or bad information for the benefit of news recipients, especially academics, because it requires the ability to filter information so as not to fall into the trap of hoax news exposed by irresponsible people. There is a fear of moral degradation caused by easy access in the digital era, it is necessary to apply character education to academics on campus even better to be applied as early as possible to elementary school students as assets of the nation's successors in order to have good character and morals in accordance with the educational objectives in Law Number 202003 concerning the National Education System.

End of 2019 and until the beginning of 2020, the world was shocked by the spread of new viruses that spread rapidly and are global in nature. WHO declared that this condition was included in the pandemic condition? Indonesia as the 4th most populous country in the world is at risk of experiencing large numbers of infections and spread of epidemics with a wide range. Responding to this pandemic situation, the Government of Indonesia is wary of the community with social-distancing and self-isolation protocols accompanied by a clean lifestyle by washing hands after touching objects. This virus outbreak is caused by a novelbeta coronavirus and is named as 2019 novel coronavirus (2019-nCoV) or Covid-19.

Social distancing as a way to cut off the spread of the Covid-19 outbreak network has resulted in lectures being held online and in accordance with technological developments and communications in the digital era of 2020. As a vigilance of Covid-19, students are also expected to be able to access information regarding outbreaks digitally and knowing the meaning, definition or translation of new terminology that is caused by the current pandemic conditions such as Coronavirus, Covid-19, ODP, PDP and Suspect so as to increase awareness of character that should be in accordance with recommended social-distancing and self-isolation protocols.

\section{Review of Literatures}

\subsection{Student Character in the Digital Age}

Psychology experts call the generation of students in 2020 as the $\mathrm{z}$ generation, digital generation or gadget generation. Generation $\mathrm{z}$ is the generation of paperless (No Paper Generation) but is always associated with the use of computers and the internet. This generation is able to access themselves in cyberspace but remain connected in communication and interaction to information and anyone who is desired without being bound by a specific time and place even in real time as the impact of technological developments in the digital age. Indonesia as a large nation and multiculturalis $m$ has a very large heritage of values in order to shape the private community to be of good character. However, phenomena in the digital era leave the impression as if the digital generation forgot to keep virtuous characters in accordance with divine values.

Institutions where students study unofficially have already implemented digital character education that must be obeyed, but in reality all of this is not enough because there is still a need to create a formal digital society program that deals with character education in the digital era in an in-depth, direct and comprehensive manner. The character education program should be built on the values determined by the community (community-defined values) where the regional head and school board (campus) discuss technology, namely in 
terms of character and digital ethics (cyber) as well as other issues that are closely related, open and honest not just discussing the integration of costs and academics.

\subsection{Translation of Students in the Digital Age}

Language is a vital means of communication for a community or between communities. With the development of the times and the emergence of new terminology as the digital era and the pandemic Covid-19 entered, language change caused many diachronic misunderstandings so students needed to strengthen their competency in intralingua translation because this type of translation could be considered intergenerational translation. Intralingua translation in the digital age is where students must be able to translate, define and understand the meaning of one language in the same terminology (term) in more detail, clear and easy to understand.

The development of communication and technology in the digital era requires continuous student translation activities with new strategies regarding the use of ICT (Information and Communication Technology) tools, namely information and communication technology in the form of hardware and software used to store, process, retrieve, collect and send data and also CAT (Computer-Assisted Translation) tools namely computerized translation technology which consists of translation memory, extracting terms, recognition tools (word translation), as well as spell checking and grammar. Success in integrating ICT and student translation skills depends on how to build student digital competencies related to computer / technology / information literacy.

\subsection{Covid-19 Understanding in the Early Digital Age 2020}

On December 31, 2019, a group of pneumonia cases that occurred in Wuhan (China) was reported to WHO (World Health Organization). The identification results state that the cause of the pneumonia case is the novel beta-coronavirus, the 2019 coronavirus novel (2019$\mathrm{nCoV}$, eventually replaced by the name SARS-COV-2 or the cause

Coronavirus disease /COVID-19) 12. In the beginning of the transmission, this outbreak was infected in China, South Korea, Iran, Italy and Japan and then spread to Europe and the United States. Covid-19 is transmitted in the body through the same cell receptors as SARS (Severe Acute Respiratory Syndrome) but is very far related to MERS (Middle East Respiratory Syndrome). Phylogenetic analysis shows the possibility that bats are the original hosts of this virus which are animals sold in the Wuhan seafood market. Structural analysis shows that COVID-19 binds to the conversion of angiotensin receptor enzyme 2 to the human body. Attempts to prevent the spread of Covid-19, the public is advised not to leave the house if there are no immediate needs such as work, illness, medical treatment and buying basic needs.

In humans, this virus can cause respiratory infections from mild in nature such as colds to those of a severe and deadly nature such as SARS and MERS. Coronavirus is currently developing and experiencing changes in variation which is then referred to as Covid-19 (Corona Virus Disease in 2019). Covid-19 began to appear at the end of 2019 and began to spread in January 2020 precisely in Wuhan City, China. The presence of this virus has successfully paralyzed all world activities from various sectors, ranging from education, business, politics, tourism and so forth. This condition does not only occur in Indonesia but also affects all countries in the world. (Saleh, 2020)

With the emergence of a new pandemic namely Covid-19 which spread globally and quickly in a short time so as to bring up new terms that should be given serious attention especially by academics including students as the successor to the nation. Students are expected to be able to understand the term with regard to the Covid-19 pandemic because it 
occurs in the digital age where information can be accessed easily. Examples of these new terms are PDP (Patients in Oversight) are those who experience respiratory distress, body heat and have been to the Covid-19 transmission area and ODP (Insider Monitoring) are those who have not shown symptoms of pain but had visited the COVID epicenter country 19 or direct contact with someone suspected of being Corona positive.

\section{Research Methods}

\subsection{Types of research}

This research uses What Sapp social media-based test and questionnaire methods with a quantitative descriptive approach. This study aims to analyze and describe the facts in the form of the characters displayed and the ability of students to translate the understanding of covid-19 in the digital era in 2020. The test method is used to collect data on the ability of translation with intralingua translation by students in understanding new terms relating to the pandemic COVID-19

While the questionnaire was used to find out the character display and the level of effectiveness of digital campus caused by students to provide tests and understanding of new terms with regard to COVID-19 via social media in the digital era in 2020. The sample in this study was 20 randomly selected students originating from from the theory of translation courses in semester 6 of unit 2 and also students of translation courses in semester 4 of unit 1 and unit 2. The sample was chosen because students were considered to be feasible and knew the types of intralinguas translation that would be used as a test in research. Student samples already have a basic knowledge regarding the tests obtained in the translation subject, namely theory of translation and translation.

\subsection{Research Stages}

Data collection procedures are carried out with a test method for understanding new terminology that emerged during the COVID-19 pandemic via online social media in the digital era and distributing online questionnaires to get the character display and the level of digital campus effectiveness by students when the corona pandemic struck. The ability of students to translate understanding of new terms in the COVID-19 period to be interpreted intralingually provided to students individually via online in the form of essay test questions in accordance with Arikunto (2010) ie the test given is a series of questions or exercises used to measure skills, knowledge, intelligence, abilities or talents of individuals and groups and Jacobs \& Chase (1992) ie every item in the test must always be planned and have an answer or something that is considered correct. Meanwhile, the questionnaire in this study was shared online using a Likert scale where the answers to each question had a gradation from very positive to very negative (suspension items as follows 5: always; 4: often; 3: sometimes; 2: rarely; and 1: never).

\subsection{Technique of Collection Data}

In order to collect data, this research will carry out (1) providing tests and analyzing test result data to determine new terminology understanding that emerged during the COVID19 pandemic via WhatsApp in the digital era by students and (2) dissemination of online questionnaires (WhatsApp / Email ) to get a display of character and the level of effectiveness of digital campuss by students while the corona pandemic. 


\subsection{Technique of Analysis Data}

The data analysis technique in this research is quantitative descriptive which uses three research activities, namely Data Reduction, Data Display, and Conclusion Drawing / Verification.

Table 1. Conversion Test Rating Score

\begin{tabular}{|c|c|c|}
\hline $\begin{array}{c}\text { Questions (COVID-19, } \\
\text { ODP, PDP, SUSPECT) }\end{array}$ & Score & Classification \\
\hline 4 & 100 & $\begin{array}{c}\text { Very well } \\
\text { understood }\end{array}$ \\
\hline 3 & 75 & Understand \\
\hline 2 & 50 & $\begin{array}{c}\text { Understand } \\
\text { enough }\end{array}$ \\
\hline 1 & 25 & $\begin{array}{c}\text { Do not } \\
\text { understand }\end{array}$ \\
\hline
\end{tabular}

\section{Result and Discussion}

The discussion of this study was taken from the results of data analysis from 20 random samples in which the samples had met the requirements to understand basic science regarding translation, especially intralingual translation, that is, translation in the form of a definition of the true meaning of the intended word or object. Questions regarding intralingual translation questions of new words that arose during the Covid-19 pandemic namely Covid-19, ODP, PDP and Suspect.

Table 2.Test Results

\begin{tabular}{|c|c|c|c|}
\hline QUESTION & Test Results & Score & Classification \\
\hline $\begin{array}{l}\text { Covid-19 / ODP / PDP } \\
\text { / SUSPECT }\end{array}$ & $\begin{array}{l}18 \text { Students are all } \\
\text { right and } 2 \text { students } \\
\text { are right } 1 \text { question } \\
\text { which is only } \\
\text { knowing Covid-19 } \\
\text { translation }\end{array}$ & $\begin{array}{lr}18 \text { students } \\
\text { scored } 100 \\
\text { and } & 2 \\
\text { students } & \\
\text { scored } 25 & \end{array}$ & $\begin{array}{l}18 \text { Students } \\
\text { understand well } \\
\text { and } 2 \text { students do } \\
\text { not understand } \\
\text { new words during } \\
\text { the pandemic }\end{array}$ \\
\hline
\end{tabular}

From the test result data it is known that $90 \%$ of students already know the intralingual translation regarding new words that come along with the Covid-19 pandemic struck, indicating that the level of translation skills of students is very well understood. They have been able to correctly answer 4 questions given where the translation of Covid-19 is the Corona virus (SARS-CoV-2) which was present at the end of 2019 with the initial spread from Wuhan city. spread of the corona virus or have had direct contact with patients who are positive for Corona, PDP is a patient under surveillance, that is a person who has been treated by a health worker and shows symptoms of contracting the corona virus and Suspect is a person suspected of having contracted the Corona virus due to close contact with a positive patient and a swab test will soon be conducted. Even so, there were still 2 students who only managed to answer 1 question regarding the Covid-19 translation and did not yet know the translation of ODP, PDP and Suspect. 
Table 3. Questionnaire Results

\begin{tabular}{|l|c|c|c|c|c|}
\hline \multicolumn{2}{|c|}{ Questionnaire } & \multicolumn{5}{|c|}{ Likert Scale } \\
\cline { 2 - 6 } & $\begin{array}{c}5 \\
\text { (Always) }\end{array}$ & $\begin{array}{c}4 \\
\text { (Often) }\end{array}$ & $\begin{array}{c}3 \\
\text { (Sometimes) }\end{array}$ & $\begin{array}{c}2 \\
\text { (Rarely) }\end{array}$ & $\begin{array}{c}1 \\
\text { (Never) }\end{array}$ \\
\hline $\begin{array}{l}\text { 1. You're up to } \\
\text { accessing a new } \\
\text { word regarding the } \\
\text { Covid-19 pandemic }\end{array}$ & 5 & 13 & 0 & 1 & 1 \\
\hline $\begin{array}{l}\text { 2. Digital Campuss } \\
\text { effectively increases } \\
\text { your interest in } \\
\text { accessing } \\
\text { knowledge, learning } \\
\text { and translation of } \\
\text { new words regarding } \\
\text { the Covid-19 } \\
\text { pandemic }\end{array}$ & 18 & 0 & 1 & 0 & 1 \\
\hline
\end{tabular}

The data above explains that the character of students to put an interest in new words that arise during the Covid-19 pandemic is very good, interested, uplifting and enthusiastic marked with a Likert scale 5 and 4 which have more number of student views than the Likert scale 3,2 and 1. Five students are always and 13 students are often interested in accessing new words with regard to Covid-19 so that from the test there were 18 students who succeeded in getting 100, while a student was rarely interested in accessing new words during this pandemic and there was even a student who had no interest in the new word regarding Covid-19 even though the spread of Covid-19 continued to spread rapidly and showed no signs of ending.

Today's students from the data look like and are able to keep up with changes and developments that are inseparable from their share of digital use and internet access. This is shown in the questionnaire data that the application of digital campuss where students can learn online has been able to increase the interest of 18 students to always take an interest in access to knowledge, learning and translation regarding the pvidemic Covid-19. The number of 18 people is the dominant number that indicates the success of digital campuss to exist effectively although there are still rare and uninterested students where the numbers are very minimal.

\section{Conclusion}

The ability of students to translate intralingually new words that were present during the Covid-19 period is very good and dominant in number. The dominant character of students in putting an interest in the knowledge, learning and translation of new words during the Covid-19 pandemic to deal with the spread of Covid-19 was very good, interested, uplifting and enthusiastic. The level of effectiveness of digital campuss by students when the corona pandemic is very high and dominant. Thank you to the LPPM \& PM Universitas Samudra from the DIPA 2020 funds and all those who assisted our research activities so that we can complete the flagship basic research. 


\section{References}

Arikunto, S. (2010). Prosedur Penelitian Suatu Pendekatan Praktik Jakarta: Rinneka Cipta. Hal.193.

Boldog, P., Tekeli, T., Vizi, Z., Denes, A., Bartha, F.A., dan Rost, G. (2020). Risk Assessment of Novel Coronavirus COVID-19 Outbreaks Outside China. Journal of Clinical Medicine. 9 (2), 571: 1-12. https://doi.org/10.3390/jcm9020571.

Hamid, A. R. A. H. (2020). Social Responsibility of Medical Journal: a concern for Covid-19 Pandemic; editorial. Medical Journal of Indonesia. 29 (1): 1-3.

Haryono, F.( 2007). Strategi Pembelajaran Era Digital: Usulan Skenario dalam Menyambut Transformasi STAIN Porwokerto sebagai salah satu PTAI yang Mengembangkan Cyberg Kampus. Jurnal Pemikiran Alternatif Pendidikan; INSANIA. 12 (1) : 17-38.

Ivanova, O. (2016). Translation and ICT Competence in the Globalized World. Journal: Procedia-Social and Behaviour Sciences. 231: 129-134. doi: 10.1016/j.sbspro.2016.09.081.

Jacobs dan Chase. (1992). Developing and Using Test Effectively. San Fransisco: JosseyBass Publishers.

Lippi, G., Henry, B. M., dan Sanchis-Gomar, M. (2020). Physical Inactivity and Cardiovascular Disease at the Time of Coronavirus Disease 2019 (COVID-19). European Journal of Preventive Cardiology. 0 (0): 1-3.

Lu, R., Zhao, X., Li, J., et al. 2020. Genomic Charaterisation and epidemiology of 2019 Novel Coronavirus: Implication for Virus Origins and Receptor Binding. Lancet. 395: 565-574.

Ohler. J. (2011). Character Education for the Digital Age. ASCD; Educational Leadership. 68 (5). Akses: http://www.ascd.org/publications/educationalleadership/feb11/vol68/num05/Character-Education-for-the-Digital-Age.aspx; Pada Tanggal 14 April 2020, Pukul: 11.39 WIB.

Ohler. J. (2011). Digital Citizenship Means Character Education for the Digital Age.Kappa Delpa Pi Record. 47 (1): 25-27. , DOI: 10.1080/00228958.2011.10516720.

Putri, D. P. (2018). Pendidikan Karakter pada Anak Sekolah Dasar di Era Digital. Jurnal Pendidikan Dasar: Ar-Riyah. 2 (1): 37-50.

Pranita, E. (2020). Tentang Virus Corona COVID-19 , Apa itu istilah ODP PDP dan Suspek?; editor: Sumartiningtyas, H. K. N. Online Article; Kompas.com.https://www.kompas.com/sains/read/2020/03/19/120200123/tentangvirus-corona-covid-19-apa-itu-istilah-odp-pdp-dan-suspek?page=2. Diakses pada 14 April 2020; Pukul 17:48 WIB.

Pranatawijaya, V. H, et al. (2019). Penerapan Skala Likert dan Skala Dikotomi Pada Kuesioner Online. Jurnal Sains dan Informatika. 5 (2): 128-137

Pratama, D. A. N. (2019). Tantangan Karakter di Era Revolusi Industri 4.0 Dalam Membentuk Kepribadian Muslim. Jurnal Manajemen Pendidikan Islam; Al-Tanzim. 3 (1): 198-226.

Pung, R., Chiew, C. J., Young, B. E., et al. (2020). Investigation of Three Clusters of Covid19 in Singapore: Implications for Surveillance and Response Measures. Lancet. Vol.395: 1039-1046.

RG, S. dan Mahmud, H. (2017). Membentuk Karakter Generasi Muda Melalui Institusi Keluarga di Era Digital. Journal of Islamic Education Management; Kelola. 2 (2): 127142. 
Sahronih, S. (2018). Implementasi Nilai-Nilai Pendidikan Karakter Dalam Mengatasi Degredasi Moral Anak Sekolah Di Era Digital. Prosiding Seminar dan Diskusi Nasional Pendidikan Dasar -UNJ. ISSN: 2528-5564. Hal. 463-468.

Saleh, A. et al. (2020). Challenges and Opportunities for Community EmpowermentPractices in Indonesia during the Covid-19 Pandemic through Strengthening the Role of Higher Education. Budapest International Research and Critics Institute-Journal (BIRCIJournal). P.1105-1113

Savas, B.(2018). Intralingual Translation as A Means of Intergenerational Communication: A Linguistic Approach. The Journal of International Social Research. 11 (55): 182-193.

Toresdahl, B. G. dan Asif, I. M. (2020). Corona Virus Disease (COVID-19): Considerations for the Competitive Athlete. Sports Health: A Multidisciplinary Approach. XX (X): 14.

Triana, D. dan Widyarto, W. O. (2013). Relevansi Kualifikasi Kontraktor Bidang Teknik Sipil Terhadap Kualitas Pekerjaan Proyek Konstruksi di Provinsi Banten. Jurnal Fondasi. 1 (1): 182-190.

World Health Organization. (2020). Global Surveillance for Covid-19 Caused by Human Infection with Covid-19 Virus; Interim Guidance. WHO reference number: WHO/2019- nCoV/SurveillanceGuidance/2020.6

Wu, Y. C, Chen, C. S dan Chan, Y. J. (2020). The Outbreak of Covid-19: An Overview. Journal of The Chinese Medical Association. 83 (3): 217-220. 